\title{
A new early Silurian prioniodontid conodont with three $P$ elements from Iran and associated species
}

Peep Männik, C. Giles Miller, and Vachik Hairapetian

Acta Palaeontologica Polonica 60 (3), 2015: 733-746 doi:http://dx.doi.org/10.4202/app.00003.2013

A prioniodontid conodont Arianagnathus jafariani gen. et sp. nov. from the late Llandovery part of the Niur Formation of the Derenjal Mountains, East Central Iran had an apparatus bearing 3 pairs of $\mathrm{P}$ elements. Pa elements of its apparatus are closest to those of Icriodella sandersi (Llandovery-Wenlock boundary interval, Wales, Great Britain) in the weak development of an icrion. Due to the small sample size not all S-elements have been identified but those present are similar to those described in the Icriodella and Icriognathus apparatuses. Based on similarities with previously described apparatus Notiodella we suggest that Arianagnathus jafariani gen. et sp. nov. probably had an apparatus of 17 elements. Arianagnathus is therefore an important additional example that has potential for aiding the future revision of the palaeobiological arrangement of elements within and the phylogeny of conodont apparatuses with $3 \mathrm{P}$ elements, one of which is icrion bearing. The completely known apparatus of associated Ozarkodina derenjalensis sp. nov. shows similarity to some unnamed Ozarkodina from Wales, Great Britain. Many of the conodonts found in the Llandovery part of the studied section are cosmopolitan; the new conodont species seem to have their possible closest relatives in Avalonia.

Key words: Conodonta, taxonomy, Llandovery, Silurian, Iran.

Peep Männik [peep.mannik@ttu.ee], Institute of Geology at Tallinn University of Technology, Ehitajate tee 5, 19086 Tallinn, Estonia; C. Giles Miller [G.Miller@nhm.ac.uk ], Department of Earth Science, Natural History Museum, London SW7 5BD, UK; Vachik Hairapetian [vachik@khuisf.ac.ir], Department of Geology, Khorasgan branch, Islamic Azad University, PO Box 81595-158, Esfahan, Iran.

This is an open-access article distributed under the terms of the Creative Commons Attribution License (for details please see creativecommons.org), which permits unrestricted use, 
distribution, and reproduction in any medium, provided the original author and source are credited.

Fafill text $(824.1 \mathrm{kB})$ 